\title{
EVALUATION OF SOME BIOCHEMICAL PARAMETERS OF RAW OF ARTEMISIA SPP. (ASTERACEAE BERCHT. \& J. PRESL.)
}

\section{Korablova Olga, Vergun Olena*, Fishchenko Valentyna, Haznyuk Mariya, Rakhmetov Dzhamal}

M.M. Gryshko National Botanical Garden of the NAS of Ukraine, Kyiv, Ukraine

Received: 1. 4.2020 Revised: 15. 4.2020 Published: 20. 11. 2020

This study was aimed to investigate the biochemical composition of plant raw material of Artemisia spp. in conditions of M.M. Gryshko National Botanical Garden of the NAS of Ukraine (Kyiv) at both budding and flowering stages. It was investigated the following species of Artemisia L. genus: A. abrotanum L., A. annua L., A. argyi H. Lev. \& Vaniot, A. austriaca Jacq., A. japonica Thunb., A. ludoviciana Nutt., and A. maritima L. The content of dry matter determined by measuring till constant weight, the total content of reducing sugars by Bertrand method, tannins with indigo carmine, titratable acidity by titration with sodium hydroxide, and ascorbic acid with 2.6-dichlorophenol-indophenol, and the content of carotene on spectrophotometer with Kalosh petrol. At the stage of budding content of dry matter was from 26.72 (A. annua) to 48.63 (A. maritima) \%, the content of reducing sugars from 5.11 (A. austriaca) to 8.93 (A. maritima) \%, the titratable acidity from 2.06 (A. abrotanum) to 3.52 (A. japonica), the tannin content from 2.77 (A. abrotanum) to 5.1 (A. ludoviciana) \%, ascorbic acid content from 11.65 (A. argyi) to 37.68 (A. japonica) $\mathrm{mg} \%$, and the content of carotene from 0.09 (A. ludoviciana) to 0.56 (A. abrotanum) $\mathrm{mg} \%$. At the stage of flowering, dry matter in raw was from 31.64 (A. annua) to 42.74 (A. austriaca) \%, the content of sugars from 6.8 (A. austriaca) to 8.23 (A. annua) \%, titratable acidity from 2.8 (A. abrotanum) to 4.66 (A. annua) \%, tannin content from 4.22 (A. austriaca) to 6.36 (A. annua) $\%$, the ascorbic acid content from 12.93 (A. abrotanum) to 65.18 (A. annua) $\mathrm{mg} \%$, and carotene content from 0.14 (A. austriaca) to 0.22 (A. annua) $\mathrm{mg} \%$. Also, at the period of budding very strong correlation was between titratable acidity and tannin content $(r=0.824)$, moderate correlation between dry matter and sugars content $(r=0.581)$. At the stage of flowering determined a very strong correlation between sugars and tannin content $(r=0.890)$, titratable acidity and tannins $(r=0.957)$, titratable acidity and ascorbic acid content $(r=0.999)$, tannins and ascorbic acid content $(r=0.966)$. In the M.M. Gryshko National Botanical Garden of the NAS of Ukraine just plants of A. abrotanum, A. annua, and A. austriaca passed in the period of flowering. Obtained data can be used for the deep further biochemical and pharmacological study.

Keywords: Artemisia, biochemical composition, correlation

*Corresponding author: Olena Vergun, M.M. Gryshko National Botanical Garden of Ukraine of National Academy of Sciences, Kyiv, Olena Vergun, Timiryazevska 1, 01014 Kyiv, Ukraine

en_vergun@ukr.net 


\section{Introduction}

Artemisia L. genus belongs to Asteraceae Bercht. \& J. Presl. family and concludes more than 200 species (Isani et al., 2019). Species of Artemisia spp. exhibited antioxidant, antimicrobial, and anti-inflammatory activities (Pavithra et al., 2018; Moacă et al., 2019). The secondary metabolite artemisinin from $A$. аппиа L. a unique sesquiterpene lactone demonstrated antimalarial properties (Knudsmark et al., 2014; Czehowski et al., 2019). A. annua is an important medicinal plant widely used in Africa for the treatment of malaria and other diseases (Chukwurah Nkachukwu et al., 2014). Also, this species has been used for centuries in Traditional Chinese Medicine. Among 600 phytochemicals identified in A. annua, the most dominated are sesquiterpenes, flavonoids, and coumarins (Isani et al., 2019). Some reviews demonstrated the antioxidant activity of $A$. annua but $A$. ludoviciana had a higher value of this parameter (Lutgen, 2018). Also, the antimicrobial activity of A. abrotanum described against gram-positive and gram-negative bacteria and Candida albicans (Ivashchenko et al., 2014).

Among secondary metabolites of A. nilagarica organs determined alkaloids (the most in shoot buds), saponins (the most in stems), steroids (the most in roots), phenols (the most in leaves), etc. (Nganthoi et al., 2016). Powder of A. annua content gross energy $3,876.7 \mathrm{kcal} / \mathrm{kg}$, total fat $3.04 \%$, cellulose $27.61 \%$, ash $8.90 \%$, amino acids (aspartic acid $1.77 \%$, glutamic acid $1.74 \%$, leucine $1.32 \%$, threonine $1.26 \%$, arginine $1.02 \%$, rest of amino acids was less $1 \%$ of content) (Panaite et al., 2018).

This study aimed to determine the peculiarities of biochemical compound accumulation in raw of different species of Artemisia L. genus in conditions of M.M. Gryshko National Botanical Garden of the NAS of Ukraine.

\section{Materiall and methodology}

\section{Biological material}

In this study investigated following species of Artemisia L. genus: A. abrotanum L., A. annua L., A. argyi H. Lev. \& Vaniot, A. austriaca Jacq., A. japonica Thunb., A. ludoviciana Nutt., A. maritima L. Plants collected from the experimental collection of Department of Cultural Flora in M.M. Gryshko National Botanical Garden of the NAS of Ukraine (NBG) at the stage of budding and flowering during 2019-2020. Biochemical analyses were conducted in the laboratory of Department Cultural Flora of M.M. Gryshko National Botanical Garden. All investigated plants are perennial.

\section{Biochemical analyses}

\section{Dry matter determination}

Plant samples were dried in drying oven at the $105^{\circ} \mathrm{C}$ till constant weight in aluminum boxes. Results are given in percentages (Hrytsajenko et al., 2003). 


\section{The total content of sugars determination}

The total content of sugars was investigated by Bertrand's method in water extracts. $4 \mathrm{~g}$ of fresh mass mixed and homogenized with distilled water (approximately $50 \mathrm{ml}$ ) in the 100 $\mathrm{ml}$ test-tubes and heated in the water bath at $70{ }^{\circ} \mathrm{C}$ during $15-20 \mathrm{~min}$. After cooling in the obtained mixtures added $1 \mathrm{ml}$ of the phosphate-oxalate mixture. After this was added $1.5 \mathrm{ml}$ of lead acetate. The obtained mixture brings to the mark $(100 \mathrm{ml})$ with water. After filtration from obtained solution took $50 \mathrm{ml}$ and mixed with $8 \mathrm{ml}$ of $20 \% \mathrm{HCl}$ (at the $70{ }^{\circ} \mathrm{C}$ in a water bath for $5 \mathrm{~min}$ ) and after cooling was neutralized by $12 \% \mathrm{NaOH}$ and brought to the mark by distilled water $(100 \mathrm{ml}) .3 \mathrm{ml}$ of obtained solution mixed with $6 \mathrm{ml}$ of Fehling's solution reagent ( 6 min boiling in the water bath). Obtained mixture analyzed for the total content of sugars. Results are given by percentages (Hrytsajenko et al., 2003).

\section{The total content of ascorbic acid}

Determination of ascorbic acid content conducted by method offered by K. Murri. $2 \mathrm{~g}$ of fresh mass mixed with $50 \mathrm{ml}$ of $2 \%$ oxalic acid. Obtained mixture put into the dark for $20 \mathrm{~min}$. Content of ascorbic acid of obtained extracts determined by a 2.6-dichlorophenol-indophenol method that based on the reduction properties of ascorbic acid. Obtained results expressed in the mg\% DW (Hrytsajenko et al., 2003).

\section{The total content of carotene}

The concentration of total carotene determined according to Pleshkov (1985) using extraction with rubber solvent (petrol). $1 \mathrm{~g}$ of absolutely dried raw mixed with $20 \mathrm{ml}$ of Kalosha petrol for 2 hours. After this obtained filtrate measured spectrophotometrically at the wavelength $440 \mathrm{~nm}$ at the Unico spectrophotometer. Obtained results expressed in $\mathrm{mg} \% \mathrm{DW}$.

\section{The total content of tannins}

The content of tannins was determined with indigo carmine as an indicator (Yermakov et al., 1972). $5 \mathrm{~g}$ of fresh mass mixed with distilled water (approximately $50 \mathrm{ml}$ ) in $100 \mathrm{ml}$ tastetubes. Obtained mixture heated in the water bath at $70{ }^{\circ} \mathrm{C}$ for 2 hours. After cooling, adding water to the $100 \mathrm{ml}$ and following filtration $10 \mathrm{ml}$ of filtrate used for determination of the total content of tannins. This procedure used $700 \mathrm{ml}$ distilled water and $25 \mathrm{ml}$ of $1 \%$ solvent of indigo carmine. Obtained results expressed in \%.

\section{The total content of organic acids}

The total content of organic acids determined with phenolphthalein and results calculated with a malic acid coefficient (Krishchenko, 1983). $10 \mathrm{ml}$ of filtrate (the same procedure described for the determination of total content of tannins) titrated with $1 \mathrm{~N}$ solvent of $\mathrm{NaOH}$ in presence of phenolphthalein. Obtained results expressed in percentages.

\section{Statistical analysis}

The mean values of three replicates and the standard deviation are given. Data submitted with ANOVA and differences between means compared using Tukey-Kramer test $(\alpha=0.05)$. Correlation analysis performed using Pearson's criterion. 


\section{Results and discussion}

Our investigation of biochemical composition and antioxidant activity of plant extracts of representatives of Asteraceae, among which Artemisia dracunculus L., Rhaponticum carthamoides Willd., Serratula coronata L., Scorzonera hispanica L., Silphium spp. have studied (Korablova and Rys, 2012; Andrushchenko et al., 2018; Vergun et al., 2018; Ivashchenko et al., 2019; Rakhmetov et al., 2019; Vergun et al., 2019).

We found the content of dry matter for plants of Artemisia spp. from 26.72 (A. annua) to 48.63 (A. maritima) \% at the stage of budding (Figure 1). Sugars are the most important regulators of many physiological processes such as photosynthesis, seed germination, flowering and processes under abiotic stresses (salt, drought, and cold stresses) (Sami et al., 2016). The study of Triticum aestivum showed that tolerant genotypes elevated reducing sugars, while susceptible plants had decline sugar content (Khan and Naqvi, 2012). The content of reducing sugars was from 5.11 (A. austriaca) to 8.93 (A. maritima) \%. The titrable acidity values of investigated plants determined from 2.06 (A. abrotanum) to 3.52 (A. japonica) \%.

One of the most important secondary metabolites tannins plays an important role in the growth of plants and act as protective compounds. They characterized by antimicrobial, antihelmintic and protein bypassed effects (Hassanpour et al., 2011). The above-ground part of plants identified tannin content from 2.77 (A. abrotanum) to 5.1 (A. ludoviciana) $\%$ at the stage of budding (Figure 1).

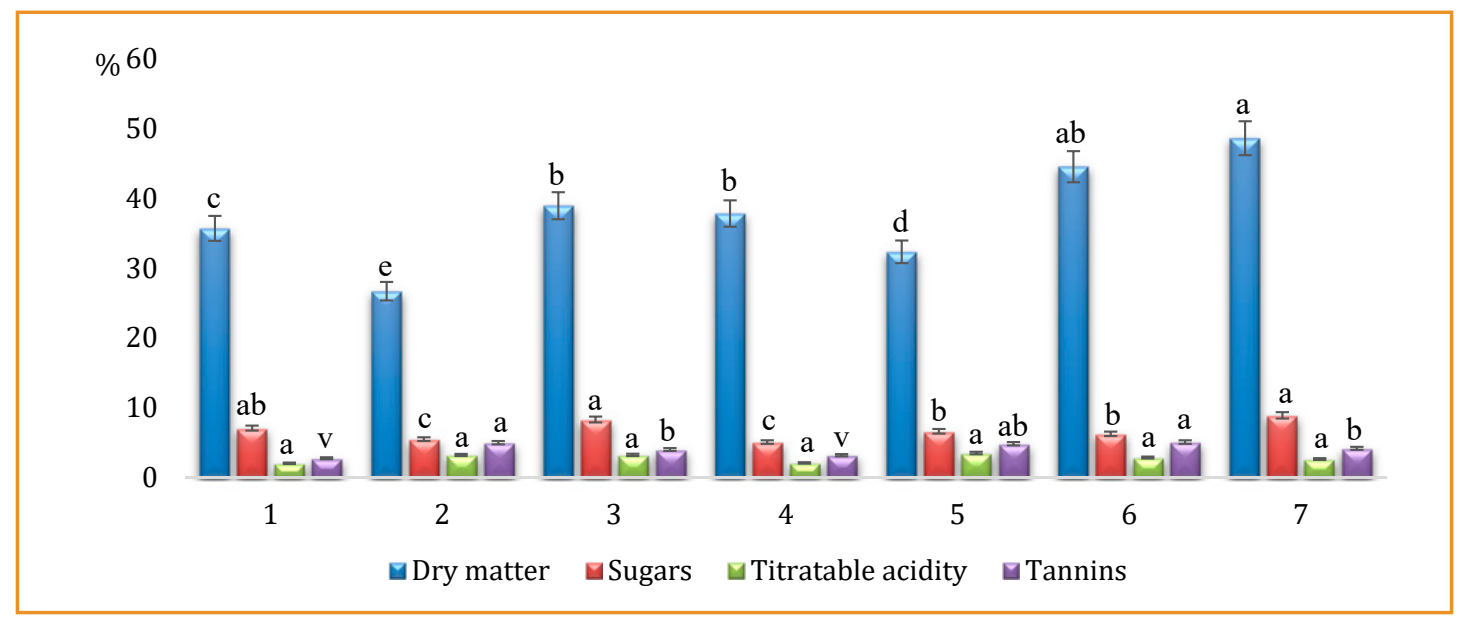

Figure 1

The content of dry matter, reducing sugars, tannins, and titrable acidity in the plant raw material of Artemisia L. species at the period of budding

1 - A. abrotanum; 2 - A. annua; 3 - A. argyi; 4 - A. austriaca; 5 - A. japonica; 6 - A. ludoviciana; 7 - A. maritima (means in columns followed by different letters are different at $p=0.05$. Each value represents the mean of three independent experiments $( \pm S D)$ )

According to Iqbal et al. (2012), the content of carbohydrates was $8.3 \%$, fat $6.09 \%$, fiber $14.2 \%$, total tannins $0.61 \%$. Tannins are naturally occurring polyphenol compounds that form complexes with proteins (Singh et al., 2012). As reported Lutgen (2018), the content of 
tannins in different organs of various species of Artemisia from Turkey, Iran, Algeria varied but leaves of $A$. annua had a higher content of tannins in approximately 10 times. Singh et al. (2012) determined the content of tannins expressed on gallic acid equivalent to $30.44 \mathrm{mg} / \mathrm{g}$ in the water extract. The dry matter of $A$. annua powder in an investigation of Panaite et al. (2018) was $88.30 \%$. Also, we determined the accumulation of ascorbic acid and carotene concentration in the above-ground part of the investigated plants (Figure 2).

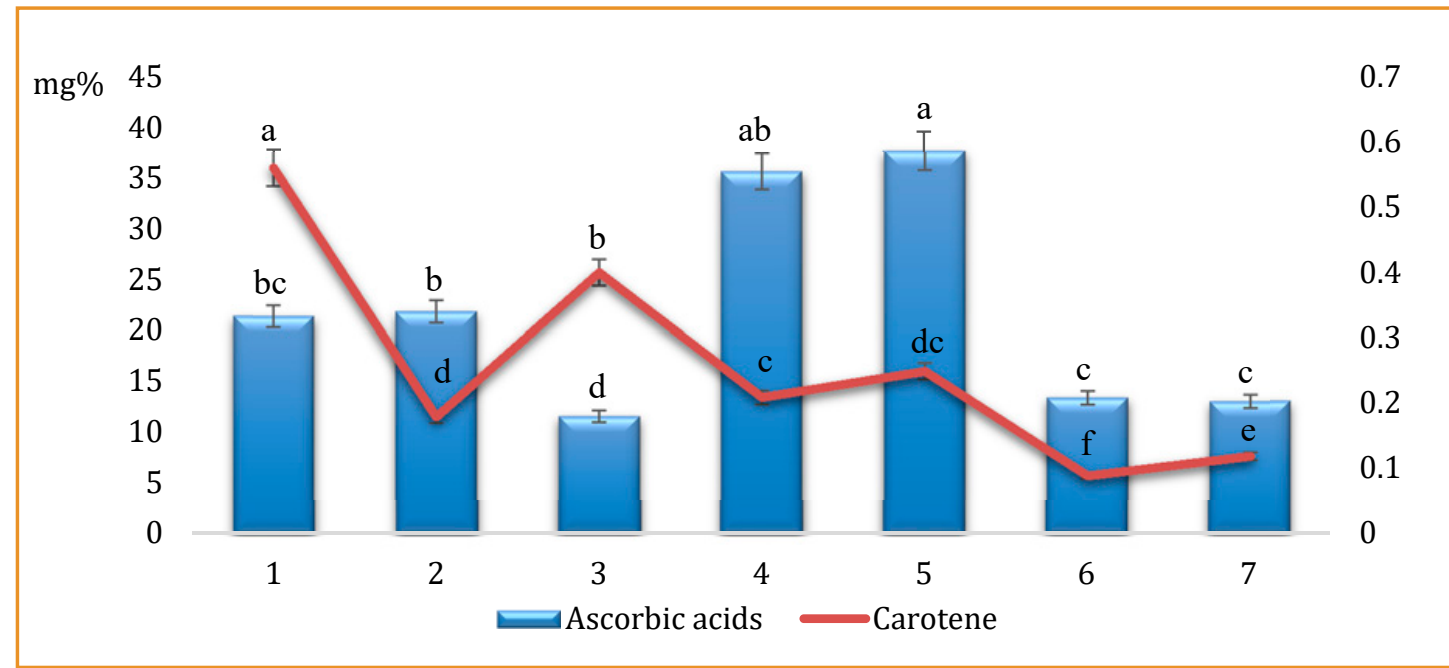

Figure 2 The content of ascorbic acid and carotene in the plant raw material of Artemisia L. species at the period of budding

1 - A. abrotanum; 2 - A. annua; 3 - A. argyi; 4 - A. austriaca; 5 - A. japonica; 6 - A. ludoviciana; 7 - A. maritima (means in columns followed by different letters are different at $p=0.05$. Each value represents the mean of three independent experiments $( \pm$ SD))

Ascorbic acid content at the stage of budding was from 11.65 (A. argyi) to 37.68 (A. japonica) $\mathrm{mg} \%$. We identified the content of carotene from 0.09 (A. ludoviciana) to 0.56 (A. abrotanum) $\mathrm{mg} \%$.

Smoylovska et al. (2010) found the content of ascorbic acid in A. absinthium during vegetation $0.035-0.113 \%$ (its matches $35-113 \mathrm{mg} \%$ ). The most content of ascorbic acid determined in the full spring vegetation and budding stage.

Observations on plant growth showed that three species only passed to the next stage of growth (flowering): A. abrotanum, A. annua, and A. austriaca. We found that the content of dry matter of three investigated plant species at the stage of flowering was from 31.64 (A. annua) to 42.74 (A. austriaca) \% (Figure 3).

Content of sugars in our study was from 6.8 (A. austriaca) to 8.23 (A. annua) \%, titrable acidity from 2.8 (A. abrotanum) to 4.66 (A. annua) \%, and tannin content from 4.22 (A. austriaca) to 6.36 (A. апnиа) \%. It should be noted that dry matter content, sugars content and titratable acidity for A. abrotanum at the stage of flowering was approximately the same as at the stage of budding, while the content of tannins at the stage of flowering increased 1.7 times. The 
Korablova, O., Vergun, O., Fishchenko, V., Haznyuk, M., Rakhmetov, D.

Agr.bio.div. Impr. Nut., Health Life Qual., 2020, 13-22

values of these investigated parameters for A. апnиа, A. austriaca increased in the stage of flowering comparing with a budding stage.

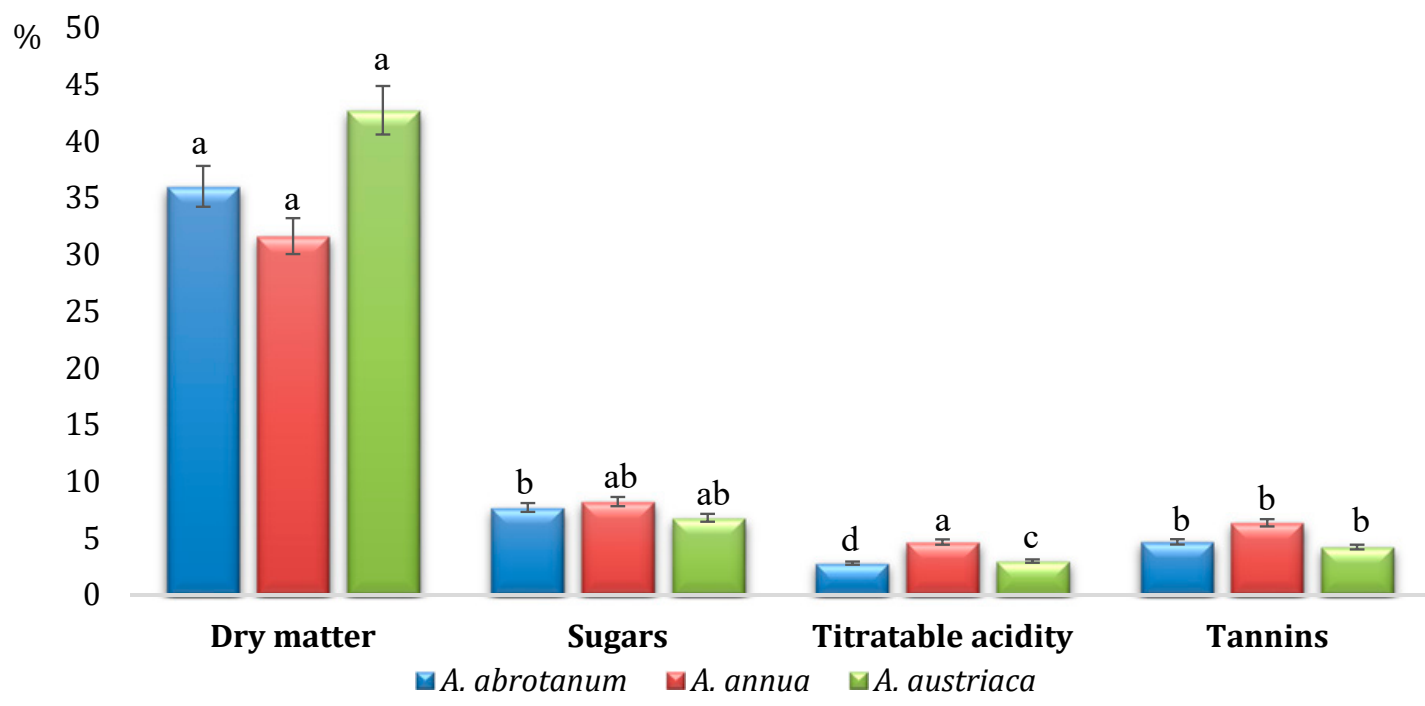

Figure 3 The content of dry matter, reducing sugars, tannins, and titrable acidity in the plant raw material of Artemisia L. species at the period of flowering (means in columns followed by different letters are different at $p=0.05$. Each value represents the mean of three independent experiments $( \pm \mathrm{SD})$ )

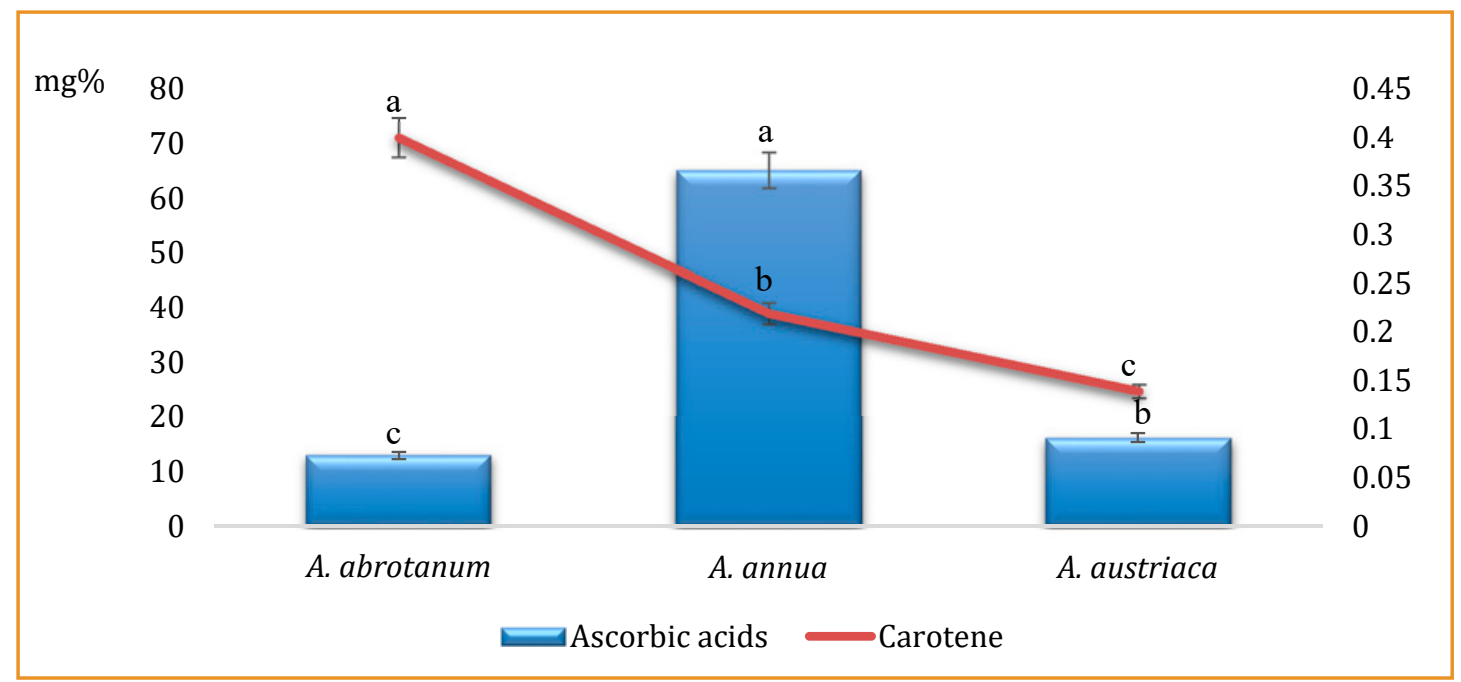

Figure 4 The content of ascorbic acid and ß-carotene in the plant raw material of Artemisia L. species at the period of flowering (means in columns followed by different letters are different at $p=0.05$. Each value represents the mean of three independent experiments $( \pm$ SD)) 
The ascorbic acid content in raw of investigated species at the stage of flowering was from 12.93 (A. abrotanum) to 65.18 (A. annua) $\mathrm{mg} \%$ (Figure 4). At the stage of flowering carotene accumulated in the range from 0.14 (A. austriaca) to 0.22 ( $A$. annua) $\mathrm{mg} \%$. Content of ascorbic acid and carotene decreased from the budding stage to flowering for $A$. abrotanum and $A$. austriaca, while for $A$. annua increased. Taking into account previous studies with A. dracunculus, the highest content of ascorbic acid found in the leaves at the stage of spring vegetation up to $730 \mathrm{mg} \%$, the least content found in stems of this species at the stage of flowering $24.6 \mathrm{mg} \%$ (Korablova, 2003).

We also conducted a correlation analysis between the accumulation of investigated compounds in two stages of growth (Table 1). We found that at the period of budding very strong correlation was between titratable acidity and tannin content $(r=0.824)$, moderate correlation between dry matter and sugars content $(r=0.581)$, a weak correlation between sugars and titratable acidity $(r=0.127)$, and very weak correlation was between carotene and ascorbic acid content $(r=0.023)$.

Table 1 Correlation analysis between investigated parameters of Artemisia spp.

\begin{tabular}{|c|c|c|c|c|c|}
\hline Parameter & Dry matter & $\begin{array}{c}\text { Sugar } \\
\text { content }\end{array}$ & $\begin{array}{c}\text { Titratable } \\
\text { acidity }\end{array}$ & $\begin{array}{l}\text { Tannin } \\
\text { content }\end{array}$ & $\begin{array}{c}\text { Ascorbic } \\
\text { acid content }\end{array}$ \\
\hline \multicolumn{6}{|l|}{ Budding } \\
\hline Sugar content & $0.581 *$ & 1 & & & \\
\hline Titratable acidity & $-0.311^{*}$ & $0.127^{*}$ & 1 & & \\
\hline Tannin content & -0.094 & -0.081 & $0.824^{*}$ & 1 & \\
\hline Ascorbic acid content & $-0.527^{*}$ & $-0.622 *$ & $-0.053^{*}$ & -0.142 & 1 \\
\hline ß-carotene content & -0.299 & $0.202^{*}$ & -0.278 & -0.690 & $0.023^{*}$ \\
\hline \multicolumn{6}{|l|}{ Flowering } \\
\hline Sugar content & -0.999 & 1 & & & \\
\hline Titrable acidity & $-0.743^{*}$ & $0.720^{*}$ & 1 & & \\
\hline Tannin content & $-0.905^{*}$ & 0.890 & $0.957^{*}$ & 1 & \\
\hline Ascorbic acid content & -0.764 & $0.741^{*}$ & $0.999 *$ & $0.966^{*}$ & 1 \\
\hline B-carotene content & -0.413 & $0.445^{*}$ & -0.302 & $-0.013^{*}$ & -0.272 \\
\hline
\end{tabular}

Note: significant according to the $t$-test $(p<0.05)$

At the stage of flowering determined a very strong correlation between sugars and tannin content $(r=0.890)$, titratable acidity and tannins $(r=0.957)$, titratable acidity and ascorbic acid content $(r=0.999)$, tannins and ascorbic acid content $(r=0.966)$. Strong correlation found sugars and titratable acidity $(r=0.720)$, sugars and ascorbic acid content $(r=0.741)$. The moderate correlation found between sugars and carotene $(r=0.445)$. Rest relations determined as negative correlated. 


\section{Conclusions}

Taking into account obtained data of the biochemical composition of Artemisia L. spp., it should be noted that in the M.M. Gryshko National Botanical Garden of the NAS of Ukraine just plants of $A$. abrotanum, A. annua, and A. austriaca passed in the period of flowering. Investigation of the biochemical composition of Artemisia species showed a very strong correlation between titratable acidity and tannin content in both budding and flowering stages, sugars and tannin content and ascorbic acid with tannin content and ascorbic acid with titratable acidity. The most content of dry matter and sugars at the budding stage was maximal in raw of $A$. maritima, titratable acidity and ascorbic acids in raw of $A$. japonica, tannin content in raw A. ludoviciana, carotene content in raw of $A$. abrotanum (as well as in flowering stage). At the flowering stage, the high content of dry matter found in raw A. austriaca, the total content of sugars, tannins, ascorbic acid, and titratable acidity in raw A. annua. Obtained data can be used for the deep further biochemical and pharmacological study.

\section{Acknowledgements}

The publication was prepared with the active participation of researchers in international network AgroBioNet.

\section{References}

ANDRUSHCHENKO, O., VERGUN, O., FISHCHENKO, V., MISHCHENKO, L. 2018. Biochemical composition Polymnia sonchifolia Poepp. at the double cutting. In Agrobiodiversity for Improving Nutrition, Health and Life Quality, vol. 2, p. 243-249. https://doi.org/10.15414/ agrobiodiversity.2018.2585-8246.243-249

CHUKWURAH NKACHUKWU, P., BRISIBE, E.A., OSUAGWU, A.N. OKOKO, T. 2014. Protective capacity of Artemisia annua as a potent antioxidant remedy against free radical damage. In Asian Pacific Journal of Tropical Biomedicine, vol. 4, p. 92-98. https://doi.org/10.12980/APJTB.4.2014C731

CZECHOWSKI, T., RINALDI, M.A., FAMODIMU, M.T., VAN VEELEN, M., LARSON, T.R., WINZER, T., RATHBONE, D.A., HARVEY, D., HORROCKS, P., GRAHAM, I.A. 2019. Flavonoid versus artemisinin anti-malarial activity in Artemisia annua whole-leaf extracts. In Frontiers in Plant Science, vol. 10, article 984. https://doi.org/10.3389/fpls.2019.00984

HASSANPOUR, SH., MAHERI-SIS, N., ESHRATKHAH, B., MEHMANSAR, F.B. 2011. Plants and secondary metabolites (tannins): a review. In International Journal of Forest, Soil and Erosian, vol. 1(1), p. 47-53.

HRYTSAJENKO, Z.M., HRYTSAJENKO, V.P., KARPENKO, V.P. 2003. Metody biologichnyh ta agrohimichnyh doslidgen roslyn i gruntiv (Methods of biological and agrochemical investigations of plants and soils). Kyiv : Nichlava, 320 p. ISSN 966-7317-84-6. Available at: http://lib.udau.edu.ua/ handle/123456789/1547 [In Ukrainian].

ISANI, G., BERTOCCHI, M., ANDREANI, G., FARRUGIA, G., CAPPADONE, C., SALAROLI, R., FORNI, M., BERNARDINI, CH. 2019. Cytotoxic effects of Artemisia annua L. and pure artemisinin on the D-17 canine osteosarcoma cell line. In Oxidative Medicine and Cellular Longevity, vol. 2019, article ID 1615758. https://doi.org/10.1155/2019/1615758

IQBAL, SH., YOUNAS, U., CHEN, K.W., ZIA-Ul-HAQ, M., ISMAIL, M. 2012. Chemical composition of Artemisia annua L. leaves and antioxidant potential of extracts as a function of extraction solvents. In Molecules, vol. 17, p. 6020-6032. https://doi.org/10.3390/molecules17056020

IVASHCHENKO, I.V., RAKHMETOV, D.B., IVASHCHENKO, O.A. 2014. Antymikrobna aktyvnist etanolnoho ekstraktu Artemisia abrotanum L. (Asteraceae) za umov introduktsii v Polissi 
Ukrajiny [Antimicrobial activity of ethanol extract of Artemisia abrotanum L. (Asteraceae) under introduction condition in Ukrainian Polissya]. In Visnyk Harkivskoho Natsionalnoho Universytetu imeni V.N. Karazina. Serija Biologichna [The Journal of V.N. Karazin Kharkiv National University. Series Biology], vol. 21, p. 97-105. [In Ukrainian]

IVASHCHENKO, I.V., RAKHMETOV, D.B., VERGUN, O.M. 2019. Biohimichni osoblyvosti introdukovanoyi populiacii Serratula coronata L. (Asteraceae) v Centralnomu Polissi Ukrainy [Biochemical features of the introduced population of Serratula coronata L. (Asteraceae) in Central Polissia of Ukraine]. In Plant Varieties Studying and Protection, vol. 15(2), p. 200-205. https://doi.org/10.21498/25181017.15.2.2019.173574 [In Ukrainian]

KHAN, N., NAQVI, N.F. 2012. Alterations in reducing sugar in Triticum aestivum under irrigated and non-irrigated condition. In African Journal of Biotechnology, vol. 11(21), p. 4849-4852. https://doi. org/4852.10.5897/AJB12.212

KNUDSMARK, J.K., DUKE, S.O., CEDERGREEN, N. 2014. Potential ecological roles of artemisinin produced by Artemisia annua L. In Journal of Chemical Ecology, vol. 40(2), p. 100-117. https://doi. org/10.1007/s10886-014-0384-6

KORABLOVA, O.A. 2003. Biologichni osoblyvosti estragonu (Artemisia dracunculus L.) v umovah introduktsii v Polissi Ukrajiny [Biological peculierities of Artemisia dracunculus L. under conditions of introduction in Polissya of Ukraine]. In Introduktsiia Roslyn [Plant Introduction], vol. 20(4), p. 106-109. https://doi.org/10.5281/zenodo.3253127 [In Ukrainian]

KORABLOVA, O.A., Rys, M.V. 2012. Introduktsiia ta selektsiia vydiv rodu Artemisia ta Monarda [Introduction and selection of species of genus Artemisia and Monarda]. In Zbereghennya ta zbagachennya roslynnyh resursiv shlyahom introduktsii ta biotehnologii [Preservation and enrichment of plant resources by introduction and biotechnology]. Kyiv : Fitosotsiocentr, p. 163-209. ISBN 978-966-306-163-7. [In Ukrainian]

KRISHCHENKO, V.P. 1983. Metody otsenki kachestva rastitelnoy produktsii (Methods of evaluation of plant production quality). M : Kolos, 192 p. [In Russian].

LUTGEN, P. 2018. Tannins in Artemisia: the hidden treasure of prophylaxis. In Pharmacy and Pharmocology International Journal, vol. 6(3), p. 176-181.

MOACĂ, E.-A., PAVEL, I.Z., DANCIU, C., CRAINICEANU, Z., MINDA, D., ARDELEAN, F., ANTAL, D.S., GHIULAI, R., CIOCA, A., DERBAN, M., SIMU, S., CHIBIOBAS, R., SZUHANEK, C., DEHELEAN, C.-A. 2019. Romanian wormwood (Artemisia absinthium L.): physicochemical and nutraceutical screening. In Molecules, vol. 24, article 3087. https://doi.org/10.3390/molecules24173087

NGANTHOI, M., HEIKRUJAM, J., KABITA, K.C., SANATOMBI, K. 2016. Screening and quantification of artemisinin and phytochemicals content in Artemisia nilagarica (C.B. Clarke) Pamp. In Journal of Plant Biology \& Soil Health, vol. 3(1), p. 1-4.

PANAITE, T.D., CRISTE, R.D., SARACILA, M., TABUC, C., TURCU, R.P., OLTEANU, M. 2018. The use of ascorbic acid in Artemisia annua powder in diets for broilers reared under heat stress. In Romanian Biotechnological Letters, vol. 23(5), p. 13976-13985. https://doi.org/10.26327/ RBL2018.159

PAVITHRA, K.S., ANNADURAI, J., RAGUNATHAN, R. 2018. Phytochemical, antioxidant and a study of bioactive compounds from Artemisia pallens. In Journal of Pharmacognosy and Phytochemistry, vol. 7(4), p. 664-675.

PLESHKOV, B.P. 1985. Praktikum po biohimii rastenii [Plant biochemistry workshop]. Moscow: Kolos, 256 p. [In Russian]

RAKHMETOV, D.B., VERGUN, O.M., STADNICHUK, N.O., SHYMANSKA, O.V., RAKHMETOVA, S.O., FISHCHENKO, V.V. 2019. Biochemical study of plant raw material of Silphium L. spp. in M.M. Gryshko National Botanical Garden. In Introdukciia Roslyn [Plant Introduction], vol. 83(3), p. 80-86. https://doi.org/10.5281/zenodo.3404144 
SAMI, F., YUSUF, M., FAIZAN, M., FARAZ, A., HAYAT, SH. 2016. Role of sugars under abiotic stress. In Plant Physiology and Biochemistry, vol. 109, p. 54-61. http://dx.doi.org/10.1016/j.plaphy.2016.09.005

SINGH, R., VERMA, K.P., SINGH, G. 2012. Total phenolic, flavonoids and tannin contents in different extracts of Artemisia absinthium. In Journal of Intercultural Ethnopharmacology, vol. 1(2), pp. 101104. https://doi.org/10.5455/iice.20120525014326

SMOYLOVSKA, G.P., GRECHANA, O.V., FUKLEVA, L.A. 2010. Fitohimichne vyvchennia kysloty askorbinovoji u roslynnii syrovyni [Phytochemical study of ascorbic acid in plant raw material]. In Farmatsiya [Pharmacy], vol. 23(4), p. 58-59.

VERGUN, O., KAČANIOVÁ, M., RAKHMETOV, D., SHYMANSKA, O., BONDARCHUK, O., BRINDZA, J., IVANIŠOVÁ, E. 2018. Antioxidant and antimicrobial activity of Bunias orientalis L. and Scorzonera hispanica L. ethanol extracts. In Agrobiodiversity for Improving Nutrition, Health and Life Quality, vol. 2, p. 29-38. https://doi.org/10.15414/agrobiodiversity.2018.2585-8246.029-038

VERGUN, O.M., RAKHMETOV, D.B., SHYMANSKA, O.V., FISHCHENKO, V.V., IVANIŠOVÁ, E. and BRINDZA, J. 2019. Leaves extracts of selected crops as a potential source of antioxidants. In Introdukciia Roslyn [Plant Introduction], vol. 84(4), p. 82-88. https://doi.org/10.5281/zenodo.3566626

YERMAKOV, A.I., ARASIMOVICH, V.V., SMIRNOVA-IKONNIKOVA, M.I., YAROSH, N.P. 1972. Metody biohimicheskoho issledovaniia rastenii (The methods of biochemical investigations of plants). Leningrad: Kolos, 456 p. [In Russian] 